\title{
INTEGRATED ANALYTICAL SYSTEM IN THE MONITORING OF CARBONIFEROUS MINE WASTES FROM THE "BOGDANKA" HARD COAL MINE
}

\author{
Zbigniew BZOWSKI \\ Department of Environmental Monitoring \\ Central Mining Institute, Katowice, Poland
}

\begin{abstract}
In order to evaluate usefulness of wastes for utilization it is necessary to use modern chemical testing methods. The proposed analytical system of the XRD-XRF-ICP-GC methods enables to conduct an examination of carboniferous waste rocks. The offered system of chemical testing is less time consuming and much more efficient. Within a reasonably short period of time, it allows to obtain information about mineralogical and chemical properties of the carboniferous waste rocks. In the paper application of such an integrated system has been illustrated with the examples drawn from the monitoring of the carboniferous wastes rocks from the "Bogdanka" coal mine.
\end{abstract}

Keywords: monitoring, analytical system, carboniferous coal wastes

\section{INTRODUCTION}

Physical and chemical testing of coal mine wastes and carboniferous coal wastes for their ecological assessment is one of the elements of the environmental monitoring. The monitoring of the carboniferous coal wastes is one of the subsystems of the complex environmental monitoring which determines conditions of the environment and forecasts environmental hazards [4].

${ }^{1}$ Corresponding author: Department of Environmental Monitoring, Central Mining Institute, Pl. Gwarków 1, 40-166 Katowice, Poland; e-mail: zbzowski@gig.eu, tel: +48322592280 


\section{MONITORING SYSTEM}

Necessity of monitoring of the carboniferous waste rocks arises from the program of monitoring the activity of mining facilities in the natural environment. Such programs help to assess the impact of the hard coal deposits exploitation on the environment. Monitoring of the wastes produced and transported by the "Bogdanka" coal mine is an element connected to the coal waste management and utilization, performed by the mine. The following points are the principal tasks of the coal waste monitoring:

- qualitative and quantitative assessment;

- assessment of waste dumps and their impact on environment;

- verification of waste management efficiency;

- stimulation of development of waste-free technologies ("cleaner production").

Implementation of the above tasks may be based on a specific Quality Waste Monitoring Program (QWMP). Apart from the quantity record, such a program should contain data for the physical-chemical assessment, as well as data on mechanical properties of the carboniferous waste rocks. Furthermore, the sampling procedure should be a part of the program. The norm for sampling of mineral aggregates can be applied in the case of carboniferous coal wastes. Monitoring of the carboniferous waste rocks from the "Bogdanka" coal mine has been incorporated in a sub-program, presented in Fig. 1.

\section{ANALYTICAL METHODS IN THE MONITORING OF THE CARBONIFEROUS WASTE ROCKS}

Investigation and assessment of the carboniferous waste rocks need a reliable integrated testing system. The measuring equipment applied for this task should limit the time of the test conduction and have a positive economic aspect. Therefore the proposed system is the XRD-XRF-ICP-GC system.

\subsection{X-ray Diffraction Spectrometry (XRD)}

Mineralogical investigations of the carboniferous waste rocks from the "Bogdanka" coal mine are performed using the diffractometer, radiation $\mathrm{CuK}_{\alpha}$ and $\mathrm{CoK}_{\alpha}$. The interpretation of the diffractograms is based on the data acquired from the ASTM and PDF-4+ files. Quantitative determinations are carried out by the use of the standardization methods [1,2, and 8].

Results of the mineral composition monitoring of the carboniferous waste rocks from the "Bogdanka" coal mine carried out in 2002 - 2010 are presented in [6], 
while the results of the monitoring taking place in 2010 - 2012 are presented in Fig. 2.

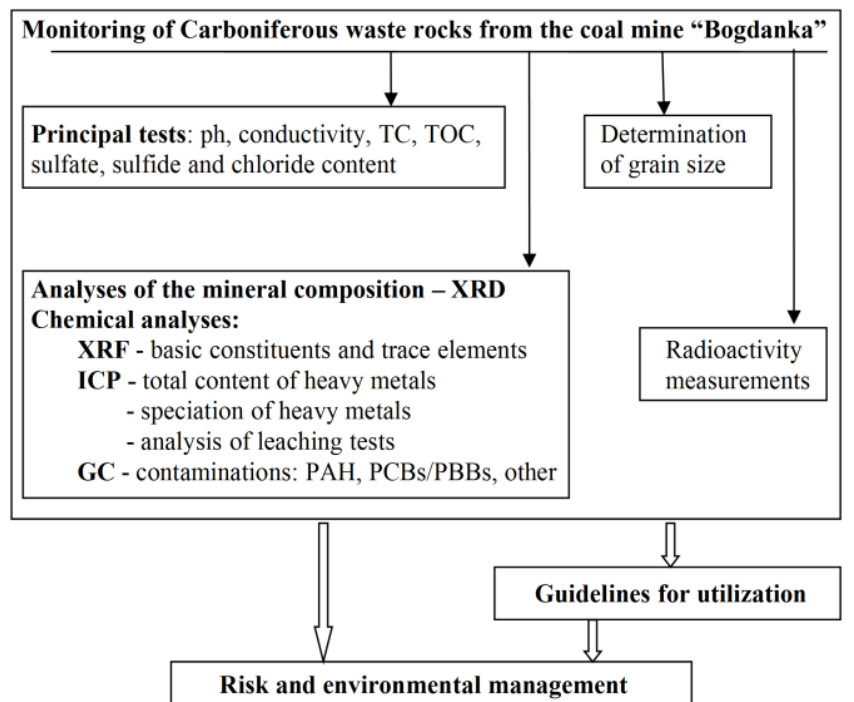

Fig. 1. Diagram of the monitoring system of the carboniferous waste rocks from the "Bogdanka" coal mine

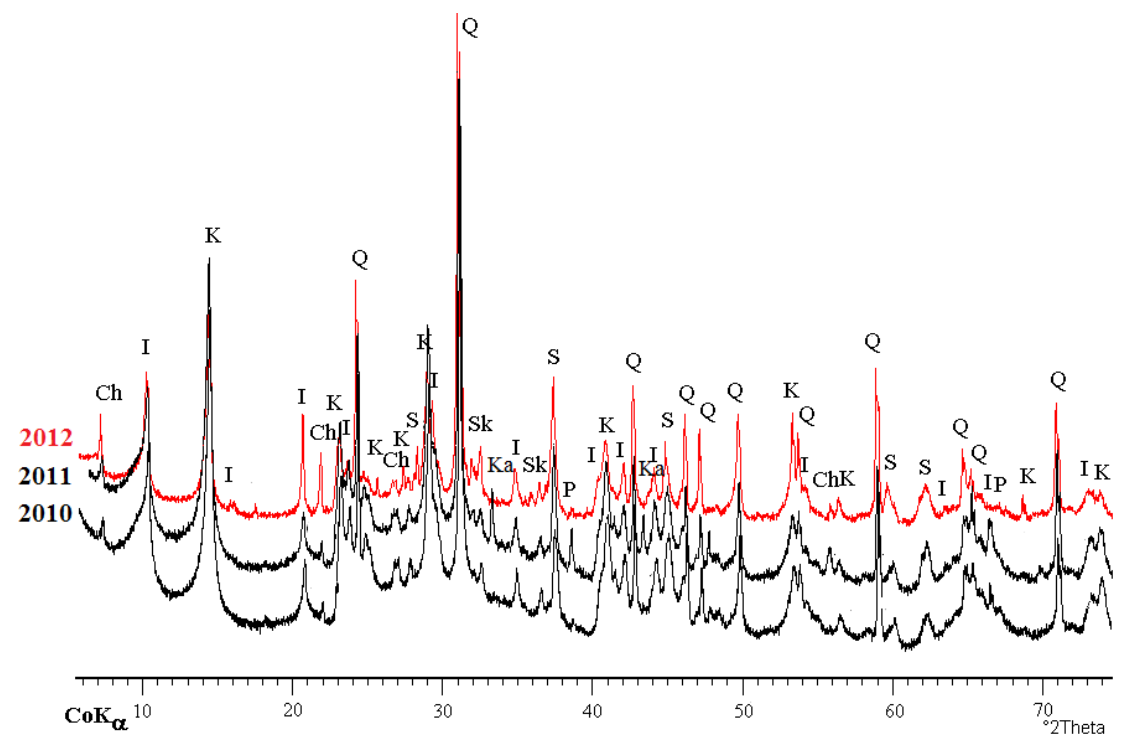

Fig. 2. Diffractograms of the mine wastes from the coal mine "Bogdanka" Description: $\mathrm{Ch}$ - chlorite, I - illite, K - kaolinite, Ka - calcite, $\mathrm{P}$ - pyrite, $\mathrm{S}$ - siderite, Sk - feldspars, Q - quartz 


\subsection{X-ray Fluorescence Spectrometry (XRF)}

The XRF method was applied for the determination of the following compounds in the carboniferous waste rocks from the "Bogdanka" coal mine: $\mathrm{SO}_{2}, \mathrm{TiO}_{2}$, $\mathrm{Al}_{2} \mathrm{O}_{3}, \mathrm{Fe}_{2} \mathrm{O}_{3}, \mathrm{CaO}, \mathrm{MgO}, \mathrm{Na}_{2} \mathrm{O}, \mathrm{K}_{2} \mathrm{O}$ and $\mathrm{P}_{2} \mathrm{O}_{5}$. Results of the chemical composition monitoring of the carboniferous wastes from the "Bogdanka" coal mine are presented in table 1.

Table 1. Main components of the coal wastes from the "Bogdanka" coal mine by the XRF method [5]

\begin{tabular}{|c|c|c|c|}
\hline \multirow{2}{*}{ Component } & \multicolumn{3}{|c|}{ Monitoring in 1996-2012; $\mathrm{n}=12$} \\
\cline { 2 - 4 } & range & average & variability \\
\cline { 2 - 4 } & \multicolumn{3}{|c|}{$\%$} \\
\hline $\mathrm{SiO}_{2}$ & $40.96-57.92$ & 47.78 & 8.8 \\
\hline $\mathrm{TiO}_{2}$ & $0.87-1.17$ & 1.04 & 10.6 \\
\hline $\mathrm{Al}_{2} \mathrm{O}_{3}$ & $18.41-25.42$ & 22.10 & 8.5 \\
\hline $\mathrm{Fe}_{2} \mathrm{O}_{3}$ & $3.14-7.66$ & 5.00 & 26.6 \\
\hline $\mathrm{CaO}$ & $0.12-1.84$ & 0.71 & 87.3 \\
\hline $\mathrm{MgO}$ & $0.76-1.92$ & 1.22 & 28.7 \\
\hline $\mathrm{Na}_{2} \mathrm{O}$ & $0.17-0.43$ & 0.30 & 30.0 \\
\hline $\mathrm{K}_{2} \mathrm{O}$ & $1.90-2.80$ & 2.28 & 12.7 \\
\hline $\mathrm{SO}_{3}$ & $0.03-0.94$ & 0.35 & 74.3 \\
\hline $\mathrm{P}_{2} \mathrm{O}_{5}$ & $0.07-0.34$ & 0.21 & 47.6 \\
\hline $\mathrm{Roasting}$ loses & $13.28-22.80$ & 18.48 & 15.5 \\
\hline
\end{tabular}

\subsection{Inductively Coupled Plasma (ICP)}

Inductively coupled plasma atomic emission spectrometry (ICP-AES) is applied for chemical investigations of leaching tests from the carboniferous wastes $[3,4,7]$. The ICP method, apart from the mentioned determination of trace elements, serves to determine many constituents in leaching tests and to investigate the speciation of metals.

Results of the heavy metals in leaching tests monitoring of the carboniferous wastes from the "Bogdanka" coal mine are presented in table 2.

\subsection{Gas chromatography (GC)}

Investigations concerning organic substances in the carboniferous waste rocks are conducted by the GC method. The monitoring is reduced to PAH and other compounds that may be dangerous for the environment (e.g. PCBs). Moreover, the frequency of the monitoring has been also reduced due to the economic aspect. 
INTEGRATED ANALYTICAL SYSTEM IN THE MONITORING OF CARBONIFEROUS 31 MINE WASTES FROM THE “BOGDANKA” HARD COAL MINE

Table 2. Heavy metals in leaching tests of the coal wastes from the "Bogdanka" coal mine by the ICP method

\begin{tabular}{|c|r|r|r|r|r|r|r|}
\hline \multirow{2}{*}{ Year } & \multirow{2}{*}{$\mathrm{pH}$} & $\mathrm{Cd}$ & $\mathrm{Cr}$ & $\mathrm{Cu}$ & $\mathrm{Ni}$ & $\mathrm{Pb}$ & $\mathrm{Zn}$ \\
\cline { 3 - 8 } & & \multicolumn{7}{|c|}{$\mathrm{Ng} / \mathrm{dm}^{3}$} \\
\hline 1996 & 7.8 & $<0.005$ & $<0.05$ & $<0.05$ & $<0.05$ & $<0.05$ & 0.03 \\
\hline 1998 & 7.6 & $<0.005$ & $<0.01$ & $<0.01$ & $<0.01$ & $<0.01$ & 0.02 \\
\hline 2000 & 6.9 & $<0.005$ & $<0.01$ & $<0.01$ & $<0.01$ & $<0.01$ & 0.02 \\
\hline 2002 & 6.9 & $<0.005$ & $<0.01$ & 0.03 & 0.06 & 0.03 & 0.07 \\
\hline 2004 & 7.6 & $<0.005$ & $<0.01$ & $<0.01$ & 0.02 & $<0.03$ & 0.02 \\
\hline 2006 & 7.25 & $<0.005$ & $<0.01$ & 0.02 & 0.03 & $<0.03$ & 0.03 \\
\hline 2007 & 8.38 & $<0.005$ & $<0.02$ & $<0.02$ & $<0.02$ & $<0.03$ & $<0.02$ \\
\hline 2008 & 7.43 & $<0.005$ & $<0.02$ & $<0.02$ & $<0.02$ & $<0.03$ & $<0.02$ \\
\hline 2009 & 7.97 & $<0.005$ & $<0.02$ & $<0.02$ & $<0.02$ & $<0.02$ & $<0.02$ \\
\hline 2010 & 8.40 & $<0.005$ & $<0.02$ & $<0.02$ & $<0.02$ & $<0.02$ & $<0.02$ \\
\hline 2011 & 8.48 & $<0.005$ & $<0.02$ & $<0.02$ & $<0.02$ & $<0.02$ & $<0.02$ \\
\hline 2012 & 8.33 & $<0.005$ & $<0.02$ & $<0.02$ & $<0.02$ & $<0.02$ & $<0.02$ \\
\hline
\end{tabular}

\section{SUMMARY}

The measurement system based on the XRD-XRF-ICP-GC/MS methods is used for the ecological assessment of the carboniferous wastes from the "Bogdanka" coal mine.

The described investigation methods serve to determine contents of such substances in the carboniferous wastes that are of particular importance in the evaluation of their risks to environment. Exemplary results of the monitoring system were presented and analyzed in the paper.

Due to the application of the presented monitoring system, the management of large amounts of wastes from the "Bogdanka" coal mine is possible. The monitoring is particularly important for the utilization of the wastes for reclamation and leveling of subsiding troughs [6]. On the other hand novel utilization methods of the carboniferous wastes may require a modification of the analytical system of the monitoring in the future.

\section{REFERENCES}

1. Albinami A,Willis B.M.T.: The Rietveld Method in Neutron and X-ray Power Diffraction, Journal of Applied Crystallography 15, 1982, 361-367.

2. Bailey S.W.: Crystal Structures of Clay Minerals and their X-ray Identyficatio., Mineralogical Society, London UK, 1980. 
3. Bojarska K., Bzowski Z.: Monitoring analysis of major and trace elements in hard coal waste by XRF and ICP methods, In Proc. ${ }^{\text {th }}$ Symp. Mine Planning \& Equipment Selection, Ostrava, Czech Rep. 1997, 835-838.

4. Bzowski Z., Bojarska K.: XRD-XRF-ICP-GC/MS Analytical System in Ecochemical Assessment for Utilisation of Carboniferous Wastes from Silesian Coal Basin (Poland), In Proc. 12 ${ }^{\text {th }}$ Symp. Mine Planning \& Equipment Selection, Kalgoorie WA, Australia, 2003, 497-500.

5. Bzowski Z, Dawidowski A.: Monitoring of the Physicochemical Composition of the Mine Wastes From The Hard Coal Mine LW "Bogdanka", Zeszyty Naukowe Uniwersytetu Zielonogórskiego 149, 2013, 87-96.

6. Bzowski Z., Szydeł R., Zarębski K., Zawiślak J.: Wytyczne dotyczqce wykorzystania odpadów wydobywczych z kopalni $L W$,Bogdanka” do niwelacji $i$ rekultywacji niecek osiadań poeksploatacyjnych, Wyd. Uniwersytet Przyrodniczy w Lublinie 2010.

7. Heasman L.: Leaching Testes to Assess the Environmental Impact of Waste, In Proc. $6^{\text {th }}$ Landfill Symposium, Environmental Sanitary Engineering Centre, Cagliari Sardinia, Italy 1997, 93-298.

8. Rodriguez-Carvajal J.: Structural Analysis from Power Diffraction Data The Rietveld Method, In Proc. Ecole Cristallographie et Neutrons, Paris, 1997.

\section{ZINTEGROWANY ANALITYCZNY SYSTEM W MONITORINGU KARBOŃSKICH ODPADÓW WYDOBYWCZYCH Z KOPALNI WĘGLA KAMIENNEGO „BOGDANKA” (LUBELSKIE ZAGŁĘBIE WĘGLOWE)}

\section{Streszczenie}

Proponowany system badań w zintegrowanym układzie analitycznym XRD-XRF-ICPGC jest prostym i proekonomicznym elementem działalności w prowadzeniu monitoringu odpadów wydobywczych. Jego wykorzystanie pozwala uzyskać w krótkim czasie informacje o mineralogicznych i chemicznych właściwościach monitorowanych odpadów wydobywczych. Dotyczy to zakresu informacji obejmujących skład mineralny (XRD) i chemiczny (XRF/ICP) oraz obecności zanieczyszczeń organicznych (GC). Wykorzystanie takiego zintegrowanego systemu badań przedstawiono na przykładzie monitoringu odpadów wydobywczych z kopalin węgla kamiennego „Bogdanka”.

Słowa kluczowe: monitoring, zintegrowany układ analityczny, odpady wydobywcze z kopalni węgla kamiennego

Editor received the manuscript: $\quad 02.04 .2013$ 